\title{
Research on Financial Support Game New Urbanization Process in China
}

\author{
Dong Xiaohong \\ School of finance, Harbin University of Commerce, University Street, Harbin, China
}

33587015@qq.com

Keywords: New urbanization; financial supply and demand; Game analysis

\begin{abstract}
Theoretical and game analysis of the new urbanization of financial support. Propose solutions to the problem of rural financial conflicts financing needs of both supply and demand, improve rural financial market stage presence financial suppression. Game analysis of the process of urbanization problems exist in our country, and then the construction of the new urbanization and rural financial support to put forward practical ideas.
\end{abstract}

\section{Introduction}

The new type of urbanization should be implemented as a national strategy, rural urbanization has become the focus of China's modernization. During the two sessions of the NPC and CPPCC in 2018, many of the proposals put forward by the deputies accounted for a large proportion of the new urbanization. New development direction of urbanization depends on the change of the pattern of economic development in our country, which associated with the construction of a well-off society in China, and the development goal of common prosperity had important influence in our country, rural urbanization as to weigh the national and regional economic development level of human society must pass a stage. According to the development trend of the world urbanization, the level of urbanization will gradually increase with the development of the overall strength of the country. But comprehensive rural urbanization is a long process, which requires a great deal of investment in manpower, material resources and financial resources.

In view of the financial impact is the main source of the fine performance and high urbanization, the new type of common financial supply problem is worthy to be further explored to promote the credit support rate of new-type urbanization, so as to promote the development of new-type urbanization. As the main force of modern economy, financial economy plays an important role in the development of new-type urbanization. There is no way for farmers with large financial service needs to meet capital needs through formal channels, so the rationality of informal finance is verified. In the face of uneven distribution of rural financial resources, especially the unbalanced allocation of credit resources, it is urgent for the government to participate in solving the imbalance of rural financial supply.

In this context, this paper analyzes the current situation of supply and demand of finance in the process of new-type urbanization in China, which draws the conclusion of the current imbalance between the supply and demand of the new type of urbanization in China. It also analyzes the situation and causes of supply and demand of the basic financial market in China. The paper puts forward some policy Suggestions on the construction of rural urbanization in China.

In the 1970s, the American economist Beatrice Peter was a developing country for the purpose of exploration, and the mainstream economic theories of the time were all aimed at developing countries. In the process of urbanization, the United States paid attention to the development of urbanization needs to be guided and regulated by the market, and the government should intervene or control it. After the First World War, the accelerated growth of the U.S. trade economy and the development of the eastern region promoted the rapid development of urbanization. The rate of urbanization in the United States had reached 60\% since the 1970 s. At the same time, because the government could not timely guide the rapid development of urbanization, it became the development status of the free management of the urbanization process, and paid a high price for it. 
Mark Dranstt (2010) pointed out that because is too big suburbanization, urban high density extends outward, soon based chaotic town which land excess energy waste and environment pollution wasserious, life and social structure was increasingly prominent. In the past, many countries in the west had increased the macro-control of the government which obtained good development benefits. For example, the British government had promulgated corresponding laws and regulations to guide the development of urbanization. Rader Alms (2011) found the rapid development of London's industrial economy after the Second World War, and the continuous expansion of the city to the periphery, which brought great pressure on agricultural land. On this basis, guide city construction land the standard development. London, however, the government set up urban-rural fringe, prevent from the rapid expansion of urban to economic, social and environmental cause losses, which formed the situation in the coordinated development of urbanization and social aspects.

The research on new-type urbanization in Chinese academia mainly lay in rural financial system policy and informal finance. A lot of work, study by Dr Guang-wen he think farmers restricted by its economic development level, even if the farmer was a big demand for financial, which could be at a disadvantage when they were in financial services, research claims should gradually promoting rural microfinance to solve the problem of new capital demand of urbanization. He guangwen (2010) analyzed the financial services and credit supply problems required by the participants and participants of rural financial transactions in China. Zhou Li (2014), according to many areas of guangdong province to the grass-roots financial supply and demand status of the research data, summarized the conclusion: for the underdeveloped areas in China, the rural financial supply could not completely meet the demand of new urbanization of funds, the government actively promoted the new urbanization, Give full play to its function, and put forward to the new adjusted by the financial demand of urbanization, and grants. Gong Minghua (2015) studied the supply of rural financial institutions in China as well as cooperation organization of regional distribution and the performance of the rural financial supply and demand imbalance, and combining the characteristics of the main body in the rural financial demand and financial demand, which could lead to the type of rural financial institutions system construction needs to solve the new imbalance of supply and demand of urbanization. It was the key to solve the imbalance between supply and demand of new urbanization in China. Agricultural development bank actively played its role and position in rural financial development, and it would relax informal financial regulation and carry out venture investment policies for projects with risks.

\section{The present situation of financing of new-type urbanization}

New type of urbanization is an important factor of economic growth in the future, we implemented the financial industry and urbanization development better, so as to bring out the resource allocation of financial industry, to speed up the process of urbanization in China's new role. Now China's dual system of financial supply and demand characteristic, it can't meet the needs of the rural micro finance users,which was the villages and towns bank for typical small financial institutions has unique advantages, which can very good satisfy grass-roots financial needs, which become the main force of rural financial development and the new urbanization construction.

\subsection{The supply of traditional formal financial institutions has declined}

In recent years, in order to solve China's rural area financial institutions share was low the financial shortage, which lacked of financial products and services such as financial impact factors, the government was encouraging some rural Banks, credit companies and fund support and establishment and development of new types of financial institutions at the grass-roots level. However, as a new force, there were still some problems in the establishment and development of new rural financial organizations in recent years, the rise of a new type of rural financial institutions to the exception, in 2007 the first formal financial institutions in China -- huimin formal financial institutions, from now on there was a lot of formal financial institutions which have been operating. Although formal financial institutions to expand faster, but in relatively backward rural areas, the development of formal financial institutions, there were many factors such as management risk was 
bigger, the lack of collateral, settlement system lag behind, etc. The existence of these constraints makes it difficult for the formal financial institutions to absorb and settle accounts, and did not provide deep services for rural financial markets. In addition, due to security concerns, formal financial institutions had been implementing a higher loan-to-deposit ratio; The single ownership structure of formal financial institutions leaded to insufficient motivation of all stakeholders; Innovation of the mode of operation and the contradiction between the old concept of management and a series of problems, which also made the formal financial institutions provide rural financial supplywas not good, the rural credit net outflow of funds was increasing year by year, which led to capital flight.

\subsection{Informal finance was abundant}

The main sources of borrowing for new-type urbanization enterprises were currently two types, one was formal financial means, such as rural credit cooperatives, rural cooperative Banks, commercial Banks and so on. The other was informal financial channels , such as classmates, relatives, and usury. Private finance had two definitions: broad and narrow. The broad definition of private finance refer to the total amount of private ownership or collective ownership of financial organizations in a new type of urbanization area. The narrow definition of rural folk finance refers to the financial institutions in rural areas but was not included in the supervision and management of the central bank or is not registered. In this paper, private finance refers to the lending behavior and economic activity of financial market fund lending behavior in the narrow sense of private finance.

\subsection{Local governments have limited financial resources}

The development of underdeveloped regions has been uneven, and the level of economic progress was lower than the national average. Increased improve the speed and quality of urbanization, need a lot of money into urban basic facilities construction and public facilities construction, which develop social capital into the urbanization level, but the lower area of the rural population urbanization rate was higher, fiscal and tax level was limited, which couldn't meet the new capital supply and demand of the construction of the urbanization, which the credit capital supply and demand gap was increasing year by year.

\section{The game analysis of new-type urbanization financial support}

The establishment of supply (formal financial institutions) and the demand subject (agribusiness) model analyzed the new urbanization between financial main body behavior on the influence of the new type of financial supply and demand of urbanization, and the new urbanization regional financial imbalance between supply and demand to analyze the reasons.

\subsection{Model establishment.}

Hypothesis 1: the participants in the credit game, namely, agricultural enterprises and formal financial institutions, were all rational economic agents, which should make the decision of economic maximization under certain conditions. In addition, all the subjects were risk averse.

Hypothesis 2: the new type of urbanization was perfect competition between formal financial institutions in financial markets, but agricultural enterprise information relative to financial institutions was insufficient, the agricultural enterprise may not tell about the information of formal financial institutions themselves, so the bank reimbursement ability of agricultural enterprises information was inadequate;

Hypothesis 3: the new urbanization financial credit market was relatively market-oriented. Theoretically, the market of agricultural enterprises should be free from any major intervention, but the fact was that the intervention of other subjects such as the government makes the market not fully marketized.

Agricultural enterprise financial supply and demand system could be understood as a process of multiple market participants in the in the mind games, and it was a step not circulation process of 
the static game, the game initiative was constantly changing, even in some cases, the power would be reversed, and policy makers first whether to send effective messages for centuries after the policy was the key of the in the mind game. Agriculture enterprise and the formal financial institutions, financial institutions as the main body in the game to build model, analysis the new urbanization area loan supply behavior as well as the possible consequences of both sides, for the new urbanization area provides the reference for the development of the financial system of supply and demand better.

Definition of related variables: C--- principal; $\mathrm{R}$-- interest rate; $\mathrm{T}$ - time limit

After $t$ years, according to the reimbursement amount of continuous compound interest, Cert, we assume that the agricultural enterprise was $\mathrm{H}$, and the financial institution of the formal financial institution was set as G.

\subsection{Game analysis}

Under the condition of complete information dynamic game analysis, the hypothesis of the current credit market, only formal financial institutions, financial institutions and agricultural enterprises have no related coordination of main intervention, formal financial institutions, and financial institutions with direct trading between agricultural enterprises. In the formal financial institutions to support financial institutions to make loans to agricultural enterprises start stage, agricultural enterprises apply for loans, determine loan after the approval of the audit, in the absence of guarantees and the mortgage, the game process between them was as follows:

The first step was that at the initial point of the game, $G$ financial institutions can have two choices, namely, lending and non-lending. If the financial institution chooses not to make loans, it has neither principal loss nor interest, so the profit value of both was 0 , and the first game of the two participants ends. If the formal financial institutions, financial institutions issue loans, so the game into the next phase, namely reach the $\mathrm{H}$ point, the second step, agricultural enterprises choose first, agricultural enterprises can choose to repay the loan and the two will not be repaid. If the agricultural enterprises choose the former, the financial institutions of the formal financial institutions can gain the benefit of $\mathrm{Ce}^{\mathrm{rt}}$, and the profits of agricultural enterprises were $\mathrm{U} 1, \mathrm{U} 1>0$; Conversely, if agricultural enterprises due to repay the loan, the formal financial institutions, financial institutions will be lost, the principal was not interest earnings of at this time - $\mathrm{Ce}^{\mathrm{rt}}$, agricultural enterprises will get extra due to not repay the loan principal and interest and income, the income of $\mathrm{U} 2(\mathrm{U} 2>\mathrm{U} 1>\mathrm{U} 0)$.

Through the analysis above, we can see the situation where the financial institutions of formal financial institutions make loans. If the loan was chosen, if the agricultural enterprise has the ability to repay the principal and interest after the maturity, the formal financial institutions can also receive the interest income and the return of the principal was Cert. However, if agricultural enterprises were unable to repay their principal and interest due to various reasons, such as bankruptcy, the formal financial institutions will have the loss of Cert. If he does not lend, not only can he keep the principal, but he can also use the money to invest in more profitable projects. Therefore, it was the key to decide whether agricultural enterprises can repay loans on time. According to assume that players were rational and economic reality, game analysis results of agricultural enterprises dominant choice or not able to repay the principal and interest, and in complete information market, information was transparent, the main body of financial supply know agricultural enterprises and the implementation of the project success and whether the ability to repay the initial capital investment, judge once can't be lending out recovery of principal and interest on time, so, don't give agricultural enterprises loans to support the implementation of the project was the optimal choice of him. This dominant result was based on the above assumption that the players of the game were rational economic people, which was the conclusion that both sides have in the complete information condition.

Actual town marginalized area market situation: to meet the participants to rational assumption, the formal financial institutions, financial supply main body would send into some of the credit funds to agricultural enterprises, most of the agricultural enterprises would repay the loan, and the 
fact that agricultural enterprises were likely to hide their lending organization information, so the game process between two essentially became the following process. Suppose that a $(1>a>0)$ represents the possibility of loan for the supplier, and $b(1>b>0)$ represents the possibility of repayment by agricultural enterprises. Under this premise, the expected return formula of financial institutions of formal financial institutions can be calculated as follows:

$$
\begin{aligned}
E(G) & =a \times[b \times \text { Cert }+(1-b) \times(-C e r t)]+(1-a) \times b \\
& =a \times \operatorname{Cert} \times(2 b-1)
\end{aligned}
$$

When $E(G)=a *$ Cert $*(2 b)>0, b>0.5$, namely agricultural enterprises the possibility of repayment was greater than $50 \%$, E (G)was positive, namely expected revenue was greater than zero, then the financial supply main body will choose to agricultural enterprises loan; When $E(G)=$ $\mathrm{a} *(2 \mathrm{~b})-1) \mathrm{Ce}^{\mathrm{rt}}<0$, namely $\mathrm{b}<0.5$, which was the possibility of loan repayment of agricultural enterprises was less than $50 \%$, the $E(G)$ was less than zero, the formal financial institutions loans expected profit less than zero, then formal financial institutions will choose not to lending. But the project prospects optimistic and have strong ability cases, agricultural enterprises should be getting paid on time, $b>0.5$, so this kind of analysis can be concluded that the new formal financial institutions in the financial markets was the hope of urbanization can be on loan from the peasants.

In the second stage of the game, if agricultural enterprises were unable to repay their loans due to bankruptcy and other reasons, then financial institutions can choose to litigate through the law. Can assume: Ct represents will occur through legal channels of transaction cost, financial institutions if wins, can recover the principal and interest and was $\mathrm{Ce}^{\mathrm{rt}}$, then the total revenue into (Ce $\left.{ }^{\mathrm{rt}}-\mathrm{Ct}\right)$, and for agricultural enterprises, lost lawsuit punished after payment of the loss of U3 (U3 > U2 > UI); Could see her financial institutions in the supply of agricultural enterprise was unable to repay or be afraid influence bank reputation and not engage in a lawsuit, the principal and interest of the loan will not be able to recover, the payment for the $\mathrm{Ce}^{\mathrm{rt}}$, the agricultural enterprise gains for U2 (U3 > $\mathrm{U} 2>\mathrm{UI}$ ). In the new type of urbanization financial markets, bank financial institutions were worried that loans made to agricultural enterprises will not be repaid, rather than loans. So early to the bank on the investigation and prospects will be investment project analysis, the final calculation project return on investment, the cost will be calculated to the rate of agricultural enterprises, and improve the agricultural enterprises in inadvertently loan threshold, the agricultural enterprise loan demand was not fully satisfied. The result was that the financial market of agricultural enterprises was in short supply.

Through the above analysis, under the condition of complete information of conventional financial institutions to consider their own interests and the new rural enterprise game the best choice was to make loans to new urbanization in the emerging enterprises. But because the new urbanization financial markets were imperfectly competitive markets, there was a wrong information, etc., in the actual circumstances of the game result is, therefore, the traditional formal financial institutions tend not to extend loans to emerging enterprises, because financial institutions always wanted to invest through competition take some prospects better for large projects.

From this perspective, financial institutions did not provide financial support to rural emerging enterprises, which resulted a more serious problem in the supply of new urbanization financial market. The behavior choice between formal financial institutions and rural emerging enterprises was an important factor which leaded to the imbalance between supply and demand.

\section{Conclusion}

In order to meet the new requirements for financial services, rural emerging enterprises of new urbanization area to improve the financial system will have relatively sound system, our country still belongs to developing countries which the development of the underdeveloped financial there are a lot of demand, so the development space is very big.Rural emerging demand for money not only confined to the small demand, and larger demand, so be sure to set up a multi-level financial system, not only to satisfy to customer, if also little customer satisfaction, so that the financial 
development in the field of new urbanization faster, go further. It can also take a certain way to speed up the progress of agricultural enterprises which improve service quality; Appropriate incentives for the development of each line; the government should step up efforts to support the development of a new type of urbanization finance.

\section{Acknowledgements}

This paper is the periodical achievement of the general project of the national social science foundation (17BJY119), Ministry of education humanities and social science research project (16YJA790067) and the social science philosophy project of heilongjiang province (16JYE01).

\section{References}

[1] Beatrice Potter., Agricultural Finance Review (2009) Agricultural Finance Review.09, 32-39.

[2] Mark Drabenstott., (2008) Concept of Agricultural business .Boston: Harvard University Press, 06, 35-40.

[3] Bruce Moorhead, Raider Alms., (2012) The Evolution of Western Agricultural policy Since 1945 [M]. London: Research in Rural Sociology and Development, 06, 20-25.

[4] CAI siping., (2015)The logic basis of the reconstruction of rural financial organization system from the perspective of interest gaming function . Financial theory and practice, 01, 2-10.

[5] Zhang songying, (2016) Thoughts on the sustainable development of rural financial markets. China securities futures, 09, 35-37. 